\title{
USE OF THE BACKHAUS MODEL IN MARKETING AND SALES-FORCE MANAGEMENT AS A PREDICTOR OF B2B BUYING BEHAVIOR
}

\author{
Darko Pantelic ${ }^{1}$ \\ University of Novi Sad, Faculty of Economics, Subotica, Serbia \\ Viktoria Sengleitner \\ University of Applied Sciences Upper Austria, School of Management, \\ Steyr, Austria
}

\begin{abstract}
Contemporary business landscape is depicted by dominant orientation towards the economy of scale, specialization and increased dependency on building strong and long-term relationship with plethora of buyers in highly competitive markets. Marketing and sales managers are placing more emphasis on building effective sales force, while theorists and practitioners are searching for models to provide guidance for this process.This paper examines the organizational buying process of business to business (B2B) companies throughframework developed by Backhaus and model proposed by Hutt and Speh. Empirical qualitative research,on the sample of Austrian companies, is conducted in order to identify main differences in purchasing processes between model and real life, and to identify the most critical processes from perspective of the buying organizations. Finally we developed suggestions for the marketing and sales side regarding what issues and steps need to be addressed in order to successfully start and develop relationship with $B 2 B$ customers.
\end{abstract}

Keywords:B2B marketing, sales management, buying behavior, purchasing center, business negotiations.

\section{INTRODUCTION}

According to number of authors the purchasing cost comprise the biggest cost part of a company (Subramaniam \& Shaw 2002; Hutt \& Speh 2007; Backhaus et al. 2013). More than a half of every dollar earned from sales is spent on the materials and equipment,thus it is not unusual to conclude that this topic is of the outmost importance for organizations. Literature review shows long history of authors that wrote about this topic, i.e. Wind, Green \& Robinson 1968; Sheth 1973; Webster \&Wind 1972; Lewin \& Donthu 2005.

Analyzing existing literature it is obvious that research of buying process and behavior is much more investigated related to B2C markets. Webster \&Wind (1972) were amongst the first researchers who started to investigate the buying process of $\mathrm{B} 2 \mathrm{~B}$ organizations. The purchasing processof industrial products,according to Backhaus \& Voeth (2010), isdistinctively different than purchasing process of consumer goods.

\footnotetext{
${ }^{1}$ darko@ef.uns.ac.rs
}

Vol. 16, бpoj 4/2014, cmp. 111-124 
Authors emphasize that $\mathrm{B} 2 \mathrm{~B}$ markets are substantially heterogeneous requiring adjustment of approach to purchasing or buying centers.

Backhaus et al. (2013) created a model that recognizes differences in the purchasing approach taking in to the consideration two main determinants:the nature of transaction and the nature of the market. It relates to previous research of Johnston \& Lewin (1996) who confirmed that the complexity and the risk of the purchase strongly influence the purchasing process and decisions.

Webster \& Wind (1972) describe industrial buying as a complex process that involves many people in the acquisition process, complexity increasedby conflicting decision criteria of different influencers and decision makers. These two authors introduced the concept of the buying center, acknowledging various individuals involved in the buying process, where each member plays a certain role or several roles. Since then much research has been conducted concerning the complexity and composition of buying centers. Different authors were searching for factors that affect decision making within organizations, as well asdifferent aspects of organizational buying behavior (Kauffmann 1996; Weiss \& Heide 1993; Steward et al. 2010).

The typology of the business has a great impact on how companies establish and realize their marketing programs (Backhaus \& Voeth 2010). Therefore Varadarajan \& Jayachandran (1999) highlight the importance of adapting the marketing strategy to the business type as an important prerequisite to achieve and sustain competitive advantage.

Main idea of Backhaus et al. (2013) emphasizes that business transaction processes in B2B can vary significantly based on the different business types.Accordingly suppliers must understand the buying process and behavior of customers in B2B markets in order to have efficient marketing and sales efforts. This is a substantially difficult task since organizations have a multiphase, multi-personal, multi-departmental and multi-objective buying process (Johnston \& Lewin 1996; Hutt \& Speh 2007).

\section{THEORETICAL SUBSTANTIATION}

Following aforementioned discourse we utilized model introduced by Backhaus et al. (1994) - the model that differentiates industrial market place into four main business types (see Figure No. 1.), which according to authors have significant impact on business buyers' behavior and decision making. Second dimension of our research framework is purchasing process, identified by Hutt and Speh (2007), with intention to use described normative process and compare it with business practice, 
Use of the Backhaus model in marketing and sales-force management as a predictor of $B 2 B$ buying behavior

allowing us to target critical steps in process related to different types of business transactions from the Backhaus model.

\section{Figure No. 1.: Four business types according to the Backhaus model}

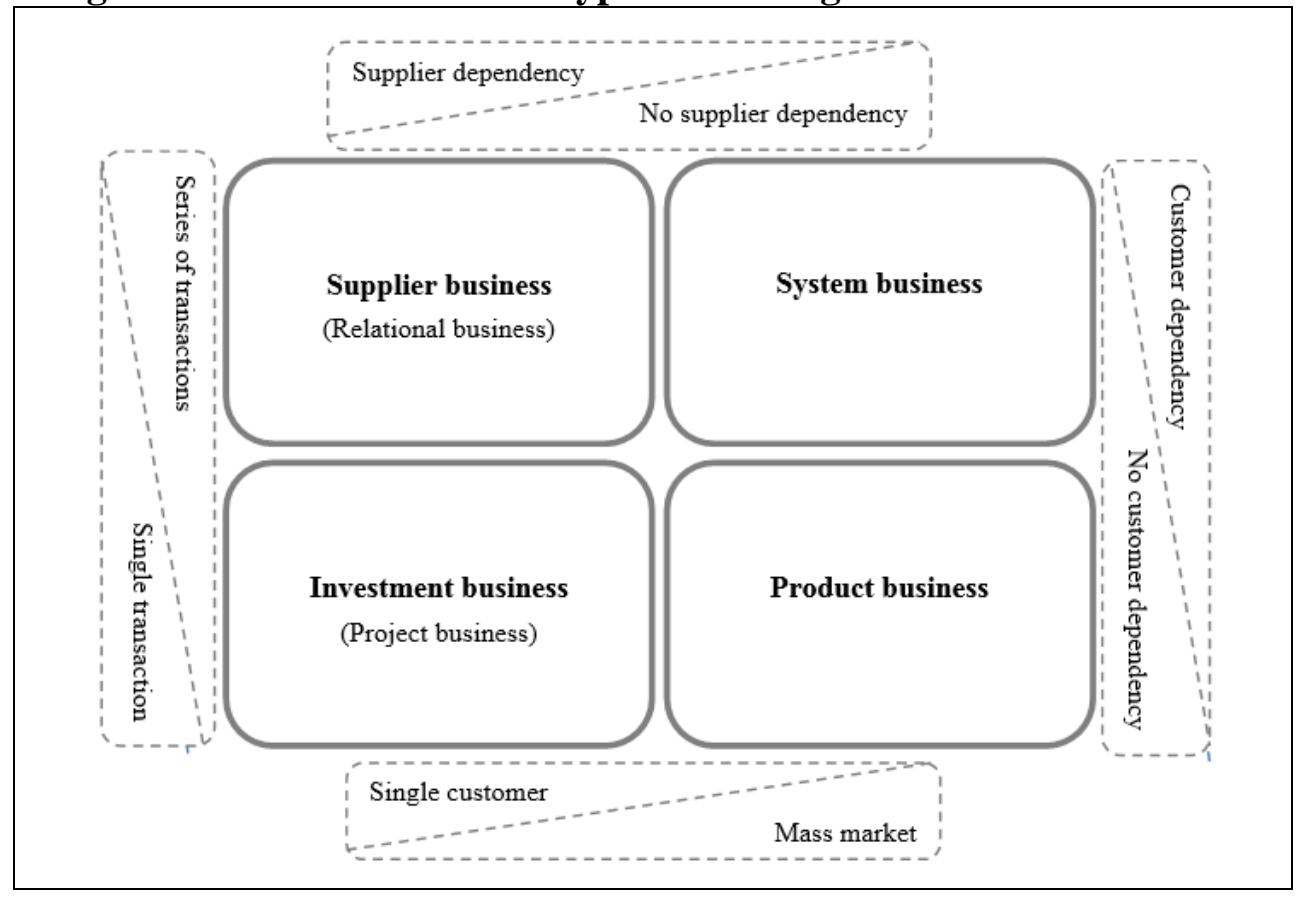

Source: adapted from Backhaus and Voeth (2010, p.206) and Backhaus et al. (2013,p.8)

Subsequent research by Backhaus \& Voeth (2010) introduced additional criterion related to degree of post-purchasing (ex-post) insecurity on these markets.Post-purchasing insecurity ranges from situations where a purchase does not have any impact on follow-up purchases (i.e.product purchases), all the way to lock-ins that tie business partners to each other for longer time periods (i.e.supplier business).

Backhouse model also incorporates specific differences that exist in doing business in series of transactions (i.e. system business) versus single transaction (i.e. investment business).

Finally original model from 1994 was refined by criterion called asset specificity(Backhaus \& Muehlfeld, 2005). The degree of asset specificity ranges from zero representing complete standardization to a $100 \%$ percent which is equivalent to total customization. Business types according to this dimension represent supplier businesses and investment businesses that require desired amount of customization whereas product businessesand system businesses allow access to the mass market from perspective of supplier, thus without customization. 
In order to develop comprehensive framework for our work, with premise that different types of businesses require different approach of marketing and sales-force we present brief overview of key business types from the Backhaus model:

I. The product business. Suppliers sell highly standardized products to customer groups that can be compared to a mass market in the consumer industry. No dependency is created between buyer and supplier (Backhaus \& Voeth 2010). Typical products in this group could be i.e. screws or office staples. Companies operating in the product business do not make specific investments related to individual customer requirements. Transaction costs are low. Even in the case of contract cancellations it is easy for the buyer to find a substitute supplier, as well as it is easy for supplier to sell its products to next buyer. Subsequent purchases are not dependent or connected, although repeated transactions or a series of transactions can also take place between the same buyer and supplier in the product business. The main challenge that companies face is the gathering of efficient market information. Purchasing companies need to closely analyze the market and gather information on products that fit their needs and requirements. The suppliers need to keep in mind that they are easily exchangeable and have to focus on communication and information policy. Adequate communication channels are advertising, promotions and/or trade fairs i.e. Price will plays a significant role, as well as branding. Common marketing tools are therefore market research and tracking customer feedback (Backhaus \& Muehlberg 2005).

II. The investment business. The investment business is also referred to as the project business by Backhaus (1999) and characterized by single transactions. The project business usually contains a high level of customization, so a termination of the contract for instance leads to significant loss for the party that invested (usually supplier). The solutions are created for specific customer needs and are highly specialized (Backhaus \& Voeth 2010).Typical products in this group could be i.e. assembly lines, plants, and machinery. Investment business has high levels of behavioral (will promised be delivered) and environmental uncertainty (will technology change affect project). Gathering large amount of information ex-ante is of the outmost importance. In order to guarantee safety for both business partiesextensive contracts are desirable. The supplier's main task is to communicate to its potential customer base its competence and expertise, as well as good-will in order to minimize the risks. Since projects last over a longer period of time,suppliers can minimize risks by aligning the payment structure to the time horizon and the investments. Apart from that it is advisable for sellers to carefully choose their customers (Backhaus \& Muehlberg 2005). 
Use of the Backhaus model in marketing and sales-force management as a predictor of $B 2 B$ buying behavior

III. The supplier business is also referred to as relational business. The business parties make investments that affect or enable a chain of transactions with an undefined horizon. Typical products in this group could be i.e. industry automations, car reflectors, etc. In order to amortize the investments the business partners have to conduct a certain amount of transactions with each other. Switching costs are immensely high as changing the transaction partner triggers a new investment, in order to start a new chain of transactions. In the relational business there is the possibility that either just one or both parties have to make investments. Based on that one party can tie the other to its product solution or both parties become dependent on each other.In contrast to the project business, contracts cannot really reduce the risk and the more intangible aspects, such as the reputation of the company become important. Decisions are made based on individual expectations, experiences and criteria such as reliability or trustworthiness of the business partner (Backhaus \& Muehlfeld 2005). Reputation management can be a very powerful tool for the supplier in relational businesses. Branding also can play a crucial part in the relational business context. From a seller's perspective innovation and flexibility are important criteria for sustainable competitive advantage.

IV. The system business. According to Backhaus \&Voeth (2010) system business is a combination of the product and the supplier business. Product examples could be: software, office furniture, etc. The system and the supplier industry are both characterized by a process of transactions. The difference is that companies in the system business sell their products to a mass market and those operating in the supplier industry are focused on customization for a small group of customers. In the system business buyers are usually highly dependent on the supplier's solutions and face high switching costs whereas the supplier can sell its products to a big group of customers.

Backhaus model is as exogenous model that allows us to categorize different types of business transactions between suppliers and buyers, enabling us to identify differences in decision making process. From the perspective of marketing and sales-force acknowledging these differences can enhance negotiation efficiency, increases persuasive power and helps build and maintain relationship with buyers by accurately addressing their needs.

Among different approaches to decision making process form buyers' center perspective we decided to follow Hutt and Speh (2007) approach. Authors identified following eight steps in organizational buying process: 
1. Problem recognition;

2. General description of need;

3. Product specification;

4. Supplier search;

5. Acquisition and analysis of proposals;

6. Supplier selection;

7. Selection of order routine;

8. Performance review.

Without ambition that we have taken all possible variables in to the account we framed our research process between the Backhaus model and Hutt \& Speh organizational buying process. Morris et al. (2001) summarize that the organizational buying process differs based on (1) the newness of the buying situation, (2) the amount and type of information that is needed and (3) the number of alternatives that are available.Selling organizations strive to understand the purchasing and decision making process of their customers in order to enhance their competitiveness. We aim to contribute with research that addresses purchasing process throughout the lens of different types of business transactions.

Based on theoretical substantiation and empirical findings we aim to answer the following research questions:

RQ1: What are the critical points of buying process related to different product types identified by Backhouse model?

RQ2: How can we utilize differences identified in buying behavior to prepare marketing and sales force for more effective relationship building with $\mathrm{B} 2 \mathrm{~B}$ buyers?

\section{EMPIRICAL RESEARCH AND METHODOLOGY}

In order to answer the research questions and to get insight into the organizational buying process the empirical research was conducted in the form of structured expert interviews. For the purpose of qualitative research structured interview guideline was developed (available by request from authors).

Structured interview guideline was tested with the owner of the small-to-medium size company mainly responsible for purchasing. Main intention was to test comprehensiveness of the Backhaus model, as well as testing the questions for clarity and deciding upon time limit for interviews. Test interview provided valuable feedback that was utilized to micro-adjust interview guideline.

The interview guideline was sent to the interview partners prior to the interviews 48 hours, withintention to enable them to prepare for the conversation and get themselves familiar with the questionnaire style. 
Use of the Backhaus model in marketing and sales-force management as a predictor of $B 2 B$ buying behavior

Interviews were conducted with nine purchasing experts from larger B2B companies in Upper Austria region. German language was used for the convenience of the interview partners.

The Backhaus model is a marketing and sales driven model, it is also dominantly used in academia, so authors had to ensure that respondents have basic understanding of the model. Short explanation and examples of transactions were provided in introductory part of interview guidelines.

In order to avoid biases organizational buying process by Hutt and Speh (2007) was not presented to the interview partners. When discussing about purchasing processes and stages they were not burdened with theoretical framework allowing us to reveal genuine business practice. criterions:

In deciding on our sample authorswere guided by three specific

A) Focus on rather large organizations when choosing the interview partners, due to the fact that SME's have rather informal approach to purchasing (Perkins and Gunasekaran 1998; Paik 2011). Additional reasoning was that with larger organizations there will be more frequency in dealing with each different type of businesses: product, system, supplier and investment business type.

B) Talk to people of the purchasing department that have a broad overview of the buying structure and process within the organization and these are preferably purchasing managers.

C) Find interview partners that could look back on long-term work experience in the field of organizational purchasing. All interview partners were highly experienced people that had worked in the field of purchasing for up to 20 years.

The following table No. 1 provides an overview of the sample.

Table No. 1.: Overview of the research respondents

\begin{tabular}{|c|c|c|c|c|}
\hline Code & Industry & Position & $\begin{array}{c}\text { No. of } \\
\text { employees }\end{array}$ & Duration \\
\hline TI & n/a & n/a & n/a & $49: 59$ \\
\hline R1 & $\begin{array}{c}\text { Automotive } \\
\text { industry }\end{array}$ & $\begin{array}{c}\text { Purchasing manager for } \\
\text { general purchasing }\end{array}$ & 2500 & $1: 00: 17$ \\
\hline R2 & $\begin{array}{c}\text { Mechanical engineering } \\
\text { industry }\end{array}$ & Purchasing manager & 4200 & $1: 10: 40$ \\
\hline R3 & $\begin{array}{c}\text { Windows and doors } \\
\text { manufacturing }\end{array}$ & Purchasing manager & 1850 & $56: 39$ \\
\hline
\end{tabular}

Vol. 16, бpoj 4/2014, cmp. 111-124 
Darko Pantelić, Viktoria Sengleitner

\begin{tabular}{|c|c|c|c|c|}
\hline $\mathbf{R} 4$ & Metal working industry & $\begin{array}{c}\text { Member of the } \\
\text { purchasing department }\end{array}$ & 500 & $55: 48$ \\
\hline $\mathbf{R 5}$ & $\begin{array}{c}\text { Industrial facilities } \\
\text { industry }\end{array}$ & Purchasing manager & 2300 & 40:08 \\
\hline $\mathbf{R 6}$ & $\begin{array}{l}\text { Polymer materials } \\
\text { industry }\end{array}$ & Purchasing manager & 590 & $55: 06$ \\
\hline $\mathbf{R 7}$ & Wholesale trade & Purchasing manager & 1000 & 58:04 \\
\hline $\mathbf{R 8}$ & $\begin{array}{l}\text { Polymer materials } \\
\text { industry }\end{array}$ & Purchasing manager & 3500 & $51: 51$ \\
\hline $\mathbf{R 9}$ & $\begin{array}{c}\text { Steel rope, fibre rope and } \\
\text { straps industry }\end{array}$ & Purchasing manager & 900 & $40: 42$ \\
\hline
\end{tabular}

Source: authors' research

All interviews were recorded in digital format, transcripts were made, and the results were analyzed by using the MAXQDA, a scientific processing program for qualitative interviews.

\section{RESEARCH FINDINGS}

The expert interviews clearly showed that the buying process of B2B organizations differs depending on which type of the product is bought. Although many of the respondents saw strong relationships between the system and the investment business, different buying processes could be identified even in this case.The authors could further identify that the steps themselves differ as well as the number of steps that are included.

The simplest purchasing process can be found in the product business, for which all interview partners emphasized the importance of an effective and time saving process. Differences in process are related to perceived importance of the product for the company operations, the more important - the more complex process becomes.

The buying process for thesystem businessis already a more extensive because most interviewees stated the risk of dependency on the supplier and the long-term aspect of the decision.

The investment business purchases are characterized by an even more complex and longer process (compared with the system business) due to the high complexity and relevance for production operations that was stated by nearly all interviewees.

The most complex and extensive buying process seems to be applied in the supplier business, especially when a R\&D phase is 
Use of the Backhaus model in marketing and sales-force management as a predictor of B2B buying behavior

included, this significantly increases the evaluation and decision making stages.

Backhaus et al. (2013) also found similar results in their study on the organizational buying process; however, different steps and phases could be identified within the scope of this research. For the product business, Backhaus et al. (2013) proposed extremely simplified process, which, according to our research, could be more complex.

According to the interviewees' statements, the sending of inquiries and the negotiation phase were included as well as an approval stage for more critical products. This is an important step in organizations that have a very systemized and strict internal purchasing procedure.

Concerning the buying process for systems business, Backhaus et al. (2013) missed the extremely important step in the establishment of criteria and specifications which was highlighted by all interviewees in this research, as well as the negotiation phase. Moreover, Backhaus et al. (2013) included the budget definition into the process, a step which was not mentioned by any interviewee in this research. In this respect respondent R1 explained, that budget is not determined within the buying process but is rather seen as the framework that is determined by either the user department or the general management of the company.

When it comes to investments business, the research indicated that there is a specific approval as crucial step for investments. Another essential step that is missing in the process of Backhaus et al. (2013) is the product specification stage. According to the interviews the contract establishment is of considerable importance and a crucial part which is therefore also regarded as a step in the buying process for investments.

In regards to the supplier business industry, a much more detailed and extensive process could be identified compared to the one of Backhaus et al. (2013). Missing elements that could be included as a result of this research are the early discussions with potential suppliers, based on which the specifications are established in a following stage. A further new finding was that many buying companies establish so called "development contracts" with several vendors which then lead to a supply contract with usually one supplier.

One of the main findings is related to the search behavior of buying organizations. The interview results provide an indication that it is not the customer that is searching for suppliers, but the suppliers searching for customers - which depicts most contemporary markets as "buyers markets". This makes the search phase in the organizational buying processes inferior to other stages. Kultti et al. (2009) stated that there are two kinds of search situations and that these are dependent on market characteristics. Either both supplier and buyer search which is 
usually the case when the buyer and vendor pool are equally sized, or one party represents a significantly larger group and is therefore seeking for the other group while the other party waits to be contacted.

Regarding the performance evaluation step that is a part of the organizational buying process of Hutt and Speh (2007), it can be stated that according to the interviewees evaluations are conducted but not as part of the buying process. There are companies such as the organization of respondents R3 or R4 that take the supplier performance evaluation very seriously and others that have a rather informal approach and see relatively few benefits in it.

An aspect that nearly all interviewees agreed on was that a systematic supplier performance evaluation system is IT supported and is only meaningful in the product and supplier business in which continuous business transactions take place. This imposes a controversial view on theproduct business type which is described in the theory as dominantly a single transaction business. However, according to the research respondents, reality looks different and most product business transactions are done in the form of framework agreements including continuous supplies. For the system business, the interview partners also regarded many business cases that fit into the system business rather as one time transactions. That is also in contradiction to the theoretical definition of the Backhaus model.

Concerning risk reducing behavior in organizational buying, the interviews showed that branding seems to be a much more important topic on the seller side, compared to the buyer side. Only one interview partner (R7) actively mentioned the relevance of brands in the decision making process. Brands might play an interesting role in some industries but in other ones not at all. Respondent R9 mentioned that brands are strongly established in the investment business, but are i.e. not important in the supplier industry.

In contrast, the importance of references and buyer-supplier relationship establishment was confirmed by the empirical research. In the systemand investment business, references help considerably in reducing the risk for the buyer. The buyer-supplier relationship is, in all four business types, imperative. Even in the product business, buying organizations prefer long-term business relationships. An exception might be the sourcing of commodities (so called $C$ parts) for which some interviewees saw benefits in regularly changing the supplier.

A final factor that should be mentioned is that the Backhaus model is an unequivocally, a marketing and sales driven model,making it not fully familiar to therespondents in the research. Consequently, buying organizations use other methods to classify the products they source. For 
Use of the Backhaus model in marketing and sales-force management as a predictor of $B 2 B$ buying behavior

example the organizations of respondents R1 and R2, divide the purchasing function into general items and production related items. Since all interview partners mentioned that investments are treated individually and independently from the other business types, this is an interesting finding that necessitates further research.

\section{CONCLUSIONS}

Analyzing available data we came to list of suggestions to marketing and sales managers that could help them create more effective and efficient marketing and sales strategies/tactics. First step in this process will require them to identify perceived business type from perspective of their business partners. This will allow them to tailor marketing and sales approach to fit expectations and needs of their customers. These findings are equally relevant for new entrants that wish to acquire new businesses, as well as for the suppliers interested in keeping their customers.

The product business. Having on mind nature of the product business it is evident that price factor is important one (respondents R1 and R2). However comparable quality is a must-have. Significant number of respondents does not prefer change of suppliers on frequent basis, which supports our conclusion that establishing buyer-supplier relationship is imperative regardless of business type. Since substitutes are widely available supplier need to be aware that change will happen if supplier does not deliver as expected or falls short on comparable offer. Respondent R2 provided idea for suppliers to attempt to transition from product to system business - capitalizing on more efficient processes, already mentioned as important criterion for the product business buyers. Bundling was also mentioned as a route to enhance efficiency of product business buyers (R3 and R5). Respondent R9 gave straightforward advice - timely delivery, quick order confirmation and delivery, as well as reporting delivery problems before it is too late, as a key elements for sustainable relationship in the product business realm. These issues were also indicated as important by R3 and R5. In the moment of truth sales force need to demonstrate ability to present efficiency driven competitive advantage of doing business with their organization (R4), as well as excellent processes tracking and delivery systems (R6).

The system business. All respondents agree on necessity to be extra sensitive about customer needs if supplier is in the system business, furthermore R1 lays out quality, price, delivery, and system and aftersales services as a key factors. Purchasing price is not the only criterion concept of the total cost of ownership nowadays represents guiding 
principle. Respondent R5 strongly suggests placing emphasis not just on selling system, but to improving buyer internal processes.According to R2 references are important and sales force needs to be reminded to put in the forefront its competence in industry. Respondents R6 and R9 called for transparency (no hidden-costs!) and openness as a routes to establish reliability and partnership with buyers.

The investment business. Infrequent large-scale purchases and long term commitment of resources are tailoring the investment business. The key element in the investment business is asset itself. Sales-force has main task to convince buyer on supplier's competence, so presentation makes all the difference. High risk calls for all means needed to persuade the other side that assets will perform and deliver expected. Respondents $\mathrm{R} 2$ and $\mathrm{R} 5$ pointed out the importance of references and branding as risk reducing factors. Newcomers in to the market will have substantially tougher position since experience with supplier is highly valued (R4). Presence in business journals and business magazines might be a potential avenue to build recognition in an industry according to respondent R6. Some of our respondents also pointed out increased role of technical department in this business type emphasizing importance of technical knowledge and necessity to work with wider and more diverse buying center. Respondent R2 brought to attention fact that often, when specifications need to be made together with vendors, buyers will tend to work initially with at least two potential partners.

The supplier business. Long term commitment and increased risk of dependency will strongly influence the supplier business partners. According to respondent R1 experience plays a vital role, since it signals competence and reliability. Several respondents emphasized price, logistic benefits or quality improvements as important for this type of business. Improvements in these categories usually result from dynamic innovations (R8 and R9), as respondent R2 mentioned suppliers in supplier business need to stay at the edge of innovation since innovations provide competitive advantages for their buyers. Following same discourse respondent R3 warned that as much as innovations are appreciated if they deliver efficiency, suppliers need to be careful with presenting them, sometimes hard push of innovation feature will trigger resistance from some of the stakeholders in buying centers, i.e. technical or manufacturing department. Respondent R6 offers solution for potential perils - feed patiently the decision makers with precise information and document it properly. Additionally, a high level of cooperation, willingness and flexibility are distinctive supplier characteristics. This is especially helpful in shortening the whole process and achieving best results. 
Use of the Backhaus model in marketing and sales-force management as a predictor of $B 2 B$ buying behavior

\section{LIMITATIONS AND FURTHER RESEARCH}

Qualitative nature of the empirical research means that all findings and conclusions can be considered as suggestions and propositions. The findings cannot be generalized, therefore the conclusions serve only as guidelines.

Research did not focus on a specific industry, the findings were collected from a variety of different organizations. Certain findings might therefore be valid only for a certain industries. Certainly increasing number of respondents would influence validity of findings.

The interviews were conducted from the perspective of the purchasing department. Consequently, the findings reflect subjective opinions from experienced purchasing experts. Analyzing the organizational buying process from another stakeholder's point of view might bring additional insights.

A possibility for further research would be to focus the analysis of the buying process on SME`s and identify whether there are differences in the process based on which different types of products are sourced.

The research sample is limited to Austrian companies and as such, it would be valuable to investigate whether international differences can also be identified when it comes to organizational buying process and behavior.

\section{REFERENCES}

1. Backhaus K.\& Muehlfeld K. (2005), "Strategy dynamics in industrial marketing: a business types perspective", Management Decision, Vol.43, No.1, pp.38-55.

2. Backhaus K. \& Voeth M. (2010), Industriegütermarketing, 9. Auflage, München: Verlag Franz Vahlen.

3. Backhaus K. (1999), Industriegütermarketing. 6. Auflage, München: Verlag Franz Vahlen.

4. Backhaus K., Aufderheide D. \& Späth G. M. (1994), Marketing für Systemtechnologien: Entwicklung eines theoretischökonomisch begründeten Geschäftstypenansatzes. Stuttgart: Schäffer-Poschel Verlag.

5. Backhaus K., Bröker O., Brüne P.\& Gausling P. (2013), "Digitale Medien in B2B Beschaffungsprozessen - eine explorative Untersuchung", accessed April 19, 2014

6. [available at https://www.marketingcenter.de/ias/forschung/ArbeitspapierNr.52.pdf] 
7. Hutt M. D. \& Speh T. W. (2007), Business Marketing Management: B2B. 9th edition, South Western: Thomson.

8. Johnston W. J. \& Lewin J. E. (1996), "Organizational buying behavior: toward an integrative framework", Journal of Business Research, Vol.35, pp.1-15.

9. Kauffman R. G. (1996), "Influences on organizational buying choice processes: future research directions", Journal of Business \& Industrial Marketing, Vol.11, No.3/4, pp.94-107.

10. Kultti K., Miettunen A., Takalo T.\& Virrankoski J. (2009), Who searches?, The Japanese Economic Review, Vol.60, No.2, pp.152171.

11. Lewin J. E. \& Donthu N. (2005), "The influence of purchase situation on buying center structure and involvement: a select meta-analysis of organizational buying behavior research", Journal of Business Research, Vol.58, pp.1381-1390.

12. Morris M. H., Pitt L. F. \& Honeycutt E. D. (2001), Business-toBusiness Marketing, a strategic approach. 3rd edition, California: Sage Publications.

13. Sheth J. N. (1973), "A model of industrial buyer behavior", Journal of Marketing, Vol.37, pp.50-56.

14. Steward M. D., Morgan F. N., Crosby L. A. \&Kumar A. (2010), "Exploring cross-national differences in organizational buyers' normative expectations of supplier performance", Journal of International Marketing, Vol.18, No.1, pp.23-40.

15. Subramaniam C.\& Saw M. J. (2002), "A study of the value and impact of B2B e-commerce: the case of web-based procurement", International Journal of Electronic Commerce, Vol.6, No.4, pp.19-40.

16. Varadarajan P. R.\& Jayachandran S. (1999), "Marketing Strategy: an assess-ment of the state of the field and outlook", Journal of the Academy of Marketing Science, Vol.27, No.2, pp.120-143.

17. Webster F. E. Jr. \& Wind Y. (1972), "A general model for understanding organizational buying behavior", Journal of Marketing, Vol.36, pp.12-19.

18. Weiss A. M. \& Heide J. B. (1993), "The nature of organizational search in high technology markets", Journal of Marketing Research, Vol.30, pp.220-233.

19. Wind, Y., Green, P. E., \& Robinson, P. J. (1968). The Determinants of Vendor Selection: The Evaluation Function Approach. Journal of Purchasing, 4(3), 29-41.

Рад је примљен: 16.12.2014. Рад је прихваћен за штампање: 24.12.2014. 